\title{
San Valentin glacier ice core (Chilean Patagonia) - Filling the gap between Central Andes and Antarctica
}

\author{
Patrick Ginot ${ }^{1}$, Françoise Vimeux ${ }^{2}$, Martine de Angelis ${ }^{1}$ and Olivier Magand ${ }^{1}$ \\ 'Laboratoire de Glaciologie et Géophysique de I'Environnement, St Martin d'Hères, France; ginot@lgge.obs.ujf-grenoble.fr \\ 2IRD Great Ice, Laboratoire des Sciences du Climat et de I'Environnement, Gif-sur-Yvette, France: vimeux@lsce.saclay.cea.fr
}

\section{Introduction}

For the last 30 years, ice core investigations along the Andes have been mainly focused in the Central Andes, between the equator and $30^{\circ} \mathrm{S}$. Major paleoclimate reconstructions covering the last 25,000 years were obtained from Quelccaya, Huascaran, Sajama (Thompson, et al., 1998), Illimani (Ramirez, et al., 2003) and Cerro Tapado (Ginot, et al., 2006). South of $60^{\circ} \mathrm{S}$, from the Antarctic Peninsula to the South Pole, the international ice core community is investigating numerous and widespread paleoclimate records, providing longer timescales. In order to understand the connection between tropical areas and high latitudes, we have set up a new ice core deep drilling program in the Chilean/Argentinean Patagonia, at $47^{\circ} \mathrm{S}$, on San Valentin and San Lorenzo summit glaciers (see project description).

\section{San Valentin ice core drilling project}

A first 16-m-long shallow ice core was extracted in March 2005 from San Valentin glacier (Fig. 1) where radar sounding indicates a glacier thickness of about 170 m (G. Casassa, pers. com.). The firn temperature measured at $16 \mathrm{~m}$ depth is $-12^{\circ} \mathrm{C}$, confirming the excellent paleoclimate signal preservation at this high altitude site. The ice core stratigraphy reveals no surface melting/refreezing ice layer. No ash or dust layer has been observed. The ice has been analyzed for ionic contents, water stable isotopes ( $\delta D$ and $\delta^{18} \mathrm{O}$ ) and some radio-nuclides. ${ }^{210} \mathrm{~Pb}$ decay and ${ }^{137} \mathrm{Cs}$ peaks indicate a time range of about 1965 to 2005, which corresponds to a mean annual accumulation rate of about 33 $\mathrm{cm}$ of snow per year (180 $\mathrm{mm}$ water equivalent). The chemical concentrations measured along the profile are extremely low, comparable to polar levels (Fig. 2). Their main
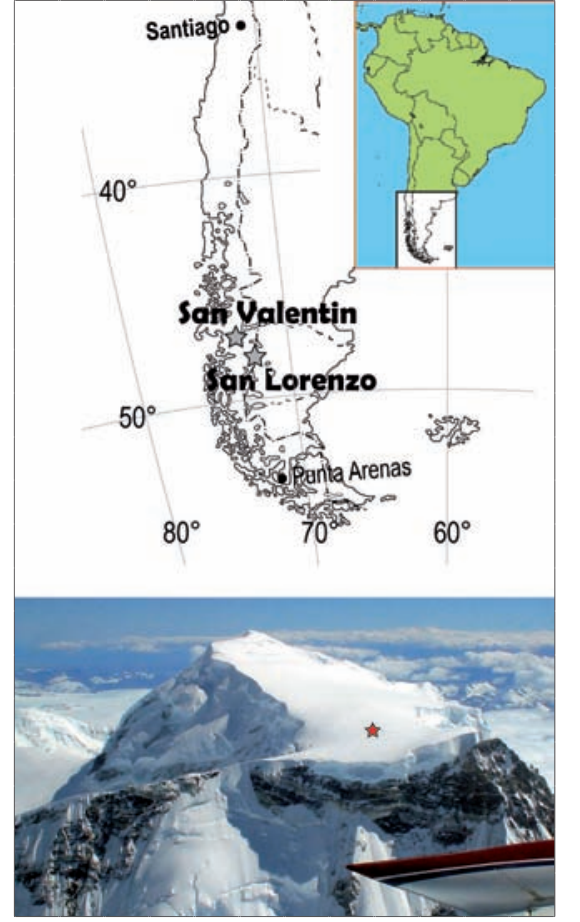

Figure 1: Top: South American map showing the location of San Valentin and San Lorenzo. Bottom: San Valentin summit glacier (photo taken from plane) showing the location of the March 2005 shallow ice core drilling site.

feature illustrates that the chemical profile is well preserved from water percolation alteration. The seasonal variations of some chemical concentrations (e.g. nss-Ca ${ }^{2+}$ ) allow annual layer counting, in agreement with the radio-nuclide dating. Some specific events are recorded: (i) Oceanic aerosol deposition, marked by sea salt peaks associated with biogenic sulfate and MSA (Methanesulfonate), were found at several depth levels (e.g. surface, $3.8 \mathrm{~m}, 7.6 \mathrm{~m}$ ); the $\mathrm{Cl} / \mathrm{Na}^{+}$ratio profile, generally close to the oceanic sea salt ratio, indicates rapid aerosol transport; (ii) Biomass burning events characterized by high nitrate concentrations associated with nssSulfate and/or nss-chloride increase were observed. The strongest event is located at $11.1 \mathrm{~m}$. These two different types of events may be related to the two main atmospheric circulation regimes: westerlies (oceanic input) or atmospheric transport from Argentinean Patagonia (fire plumes). Further investigations are needed to deconvoluate the sulfur signal, and so, to locate the main volcanic eruptions over this time period (e.g. Cerro Hudson 1991). The water stable isotope content $\left(\delta D, \delta^{18} O\right)$ of the ice was measured with a twice-lower sampling resolution, which does not allow us to clearly distinguish the seasonal variations (Fig. 2). However, the dry/wet season alternation, as revealed by the aerosol profiles, matches the narrow peaks in the isotopic profile. Moreover, the isotope profile exhibits an interesting interannual signal that should be further discussed. Deuterium excess has also been calculated (not shown). The $\delta \mathrm{D} / \delta^{18} \mathrm{O}$ slope is 8.64 , confirming that no melting at the surface occurs. Deuterium excess exhibits a large range from about 4 to $18 \%$, strongly suggesting large fluctuations in airmass origins and trajectories. This is in agreement with what has been inferred from chemical profiles.

The promising results from this preliminary study have lead us to plan deeper drilling operations in this area in April/May 2007. An ice

Project facts:
The Sanvallor project deals
with two deep ice cores at San
Valentin glacier (Chile, $3747 \mathrm{~m}$,
$46^{\circ} 35^{\prime} 19^{\prime \prime} \mathrm{S}, 73^{\circ} 19^{\prime} 39^{\prime \prime} \mathrm{W}$ ) and San
Lorenzo glacier (Chile/Argentina,
$\left.\sim 3500 \mathrm{~m}, \sim 47^{\circ} 32^{\prime} \mathrm{S}, 72^{\circ} 20^{\prime} \mathrm{W}\right)$. It
started in 2005, with the prelimi-
nary study on the shallow core,
and should run until 2009 . The
preliminary study was funded by
IRD-Great Ice, LSCE, LGGE and
CECS Valdivia (Centro de Estu-
dios Cientificos). The first deep
drilling operations attempt was
funded by the Chilean Fondecyt
and IRD. A proposal has been
submitted to fund the analyses.




\title{
Science Highlights: Open Section
}

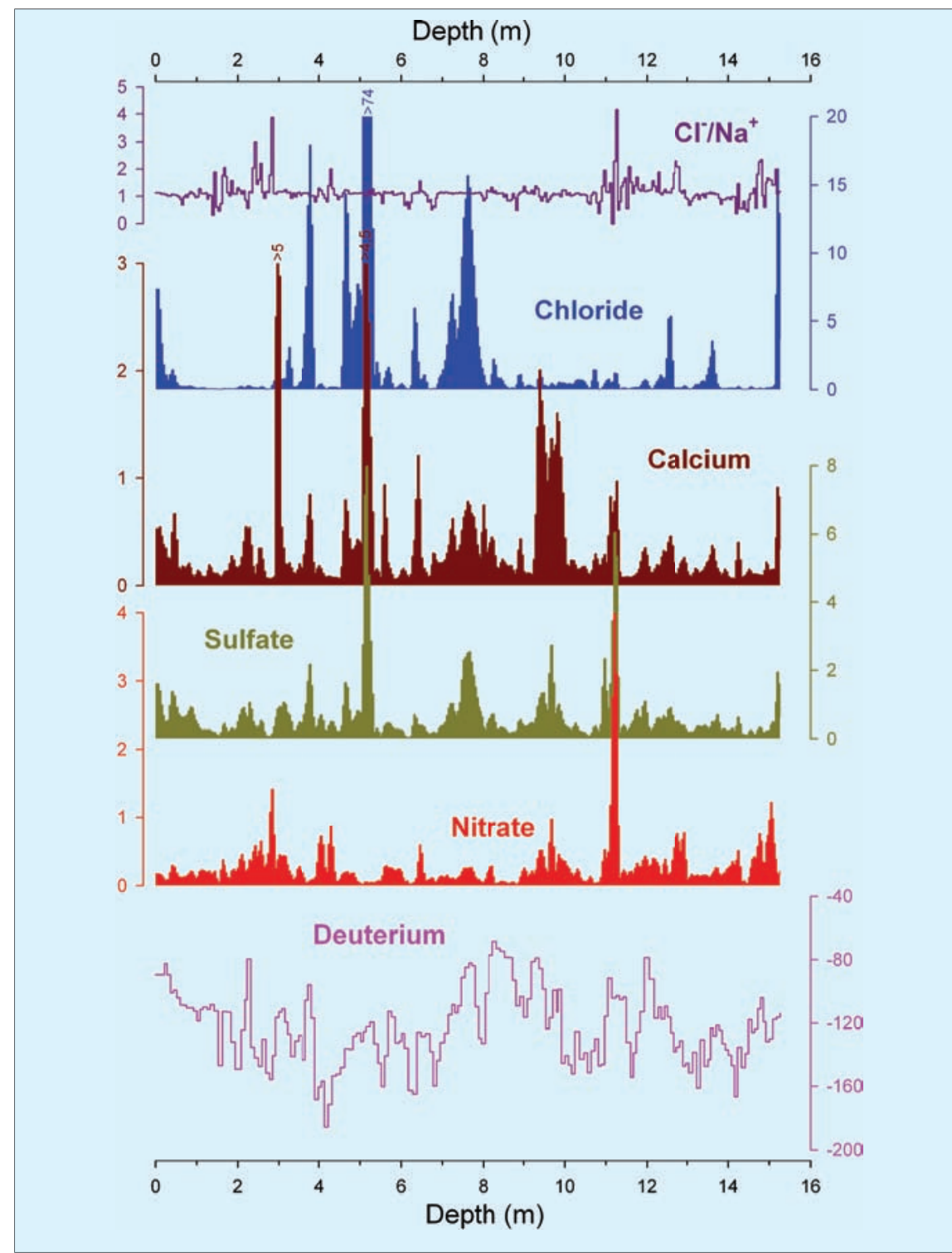

core will be recovered down to the bedrock by IRD Great Ice and its partners on the San Valentin site, and some preliminary investigations performed on the San Lorenzo glacier, about $50 \mathrm{~km}$ farther southeast. Ice thickness and estimated accumulation rate on San Valentin allow us to expect paleoclimate reconstructions at high resolution over, at least, the last 2000 years. The deepest part of the ice cores might include the Last Glacial Maximum. Ice will be dispatched to all the participating laboratories. The ice core diameter will permit us to provide enough material to establish all the profiles with the required resolution.

\section{REFERENCES}

Ginot, P., Kull, Ch., Schotterer, U., Schwikowski, M. and Gäggeler, H.W., 2006: Glacier masse balance reconstruction by sublimation induced enrichment of chemical species on Cerro Tapado (Chilean Andes), Climate of the Past, 2: 21-30.

Ramirez, E., Hoffmann, G., Taupin, J.D., Francou, B., Ribstein, P., Caillon, N., Ferron, F.A., Landais, A., Petit, J.R., Pouyaud, B., Schotterer, U., Simões, J.C. and Stievenard, M., 2003: A new Andean deep ice core from Nevado Illimani (6350 m) Bolivia, Earth and Planetary Science Letters, 212 337-350.

Thompson, L. G. Davis, M.E., Mosley-Thompson, E., Sowers, T.A., Henderson, K.A., Zagorodnov, V.S., Lin, P-N, Mikhalenko, V.N., Campen, R.K., Bolzan, J.F., Cole-Dai, J. and Francou, B., 1998: A 25000year tropical climate history from Bolivian ice cores, Science, 282: 1858-1864.

Figure 2: Selected chemical concentration $\left(\mu \mathrm{Eq} . \mathrm{L}^{-1}\right)$, ratio and $\delta D(\%$ versus SMOW) profiles measured along the San Valentin 16-m-long shallow ice core extracted in March 2005.

\section{Sediment, pollen and isotope evidence for an Early to Mid-Holocene humid period in the desert of Yemen}

\author{
Anne-Marie Lézine ${ }^{1}$, Christian Robert ${ }^{2}$, Jean-François Saliège ${ }^{3}$ and Jean-Jacques Tiercelin ${ }^{4}$ \\ 'Laboratoire des Sciences du Climat et de l'Environnement, UMR 1572 CNRS-CEA, Gif-sur-Yvette, France; anne-marie.lezine@cea.fr \\ ${ }^{2}$ CEREGE, Aix-en-Provence, France; robert@cegere.fr \\ 'Laboratoire d'Océanographie et du Climat, UMR 7159 CNRS-IRD-UPMC, Paris, France; Jean-Francois.Saliege@lodyc.jussieu.fr \\ 4IUEM, UMR 6538 CNRS-UBO, Plouzané, France; jjtierc@univ-brest.fr
}

\section{Introduction}

Environmental reconstructions of tropical deserts during the Holocene have mainly focused on Northern Africa. There, numerous lake-level and pollen data have been extensively used for regional reconstruction of past hydrological or vegetation changes, as well as for paleoclimatic models connecting environmental changes with variations in the Earth's orbit or in- vestigating atmosphere-vegetation feedback in the climate system. By contrast, very little is known about the environmental and climate history of Arabia, even though recent discoveries of speleothems in Oman (Fleitmann et al., 2003) have yielded high-resolution oxygen isotope records reflecting variations in the Indian monsoon rainfall during the Holocene. However, the northern penetration of the Indian monsoon inland and its impact on hydrology and vegetation are only poorly understood because of the scarcity of continuous continental sedimentary archives. Here, we present the first continuous record of environment and climate in Southern Arabia, based on sedimentological, mineralogical, pollen and isotope studies of al-Hawa (Yemen) paleolake, which covers the time interval from 12 to $7.5 \mathrm{ka} \mathrm{BP}$. 